\title{
Чимаров С.Ю. \\ Онлайн-технологии формирования параллельных структур правосудия и следствия в Республике Беларусь как фактор информационного противоборства
}

Санкт-Петербургский университет МВД России (Россия, Санкт-Петербург)

doi: $10.18411 / 1 j-02-2021-17$

idsp: ljournal-02-2021-17

\section{Аннотация}

В статье представлен анализ попыток лидеров белорусского протестного движения по дестабилизации общественного порядка в стране посредством апеллирования к народному сознанию, нацеленному на учреждение новых «независимых» правоохранительных структур. Выявляя ареал используемых форм и средств дигитального воздействия на общество при помощи современных мессенджеров и специальных онлайн-проектов, автор акцентирует внимание на новой тактике информационного противостояния в обществе и особой роли новых технологий цифровой коммуникации.

Ключевые слова: онлайн-технология, органы внутренних дел, правоохранительные структуры, социальная сеть, сетевое пространство, информационное противоборство, фронт правосудия.

\section{Abstract}

The article presents an analysis of the attempts of the leaders of the Belarusian protest movement to destabilize public order in the country by appealing to the popular consciousness aimed at establishing new "independent" law enforcement structures. Revealing the area of used forms and means of digital influence on society with the help of modern instant messengers and special online projects, the author focuses on the new tactics of information confrontation in society and the special role of new digital communication technologies.

Keywords: online technology, internal affairs bodies, law enforcement agencies, social network, network space, information confrontation, the front of justice.

Эффективность функционирования современной парадигмы общественной жизни в значительной степени предопределяется прочностью моральных связей социального доверия. Согласно выводу американского философа Ф. Фукуямы, ключевым фактором благополучия в обществе выступает масштаб социального капитала, представленного доверием. При этом значимость уровня доверия не уступает по силе своего воздействия на общество силе физического капитала. Более того, радикальный отход от существующей коммунитарной традиции выступает предтечей общественной нестабильности [6]. Стабильность общественных устоев корреспондирует доверию общества ко всей системе правоохранения в государстве. К примеру, оценивая соотношение уровня социального доверия с доверием к судебной системе, председатель Совета судей Российской Федерации В.В. Момотов констатирует, что неотъемлемой частью реализации принципов демократического и правового государства, укрепления авторитета и независимости судебной власти выступают: во-первых, соответствие поведения судейского сообщества современным стандартам и ожиданиям гражданского общества; во-вторых, диалог и взаимодействие между судейским сообществом, институтами гражданского общества и СМИ [1]. Разрыв действующих связей социального взаимодействия и подрыв авторитета различных правоохранительных институций, с опорой на потенциал современных онлайн-технологий, активно используется в отдельных странах, оказавшихся в водовороте внутриполитического противостояния. Примером отмеченного служат 
события в Республике Беларусь с августа 2020 г. по настоящее время. Следует заметить, что центральным направлением информационных онлайн-атак на систему правоохранения, подпитывающих «родники» народного недовольства, выступает попытка формирования параллельных структур правосудия и следствия в Республике Беларусь в формате «фронта правосудия» единого «Плана Победы» [2], активно продвигаемого в сознание населения посредством свода «Telegram»-каналов и специальных сетевых проектов.

Ключевыми информационными ресурсами «фронта правосудия» в Республике Беларусь выступают: сайт «Единая книга регистрации преступлений» (ЕКРПhttps://ekrp.org/); инициатива «ByPol» (https://t.me/By_Pol), являющаяся объединением сотрудников белорусских правоохранительных ведомств; специальный проект «2334.net.»; правозащитный центр «Весна»; сайт «Соучастники преступлений» (https://crime.honest-people.by/); сайт и «Telegram»-канал «Черная книга Беларуси» (https://t.me/BlackBookBelarus); «Telegram»-каналы Движения «Голос» (https://t.me/votebelarus2020), проектов «ZUBR» (https://t.me/zubr_in) и «Август 2020» (https://t.me/august2020by), а также ряд иных мессенджеров («Viber», «Skype», «WhatsApp», «Facebook Messenger»).

В целях преодоления факта блокирования входа на отдельные сайты и «Telegram»-каналы предлагаются соответствующие методические рекомендации. К примеру, для входа на сайт «ЕКРП» рекомендуется использование четырех VPN сервисов виртуальных частных сетей (англ. «Virtual Private Network»): «Tunnel Bear»; «Psiphon»; «Open VPN»; «NORD VPN», обеспечивающих VPN-соединение между пользователем и сервером по зашифрованному каналу связи. Миссия указанных ресурсов заключается в фиксации и обнародовании фактов нарушения правоохранителями и чиновниками прав человека, включая штрафы, аресты, и суды, связанные с акциями протеста, а также социальное давление на данную категорию служащих посредством направления им сигналов социального осуждения и деанонимизации их личности. Источником доказательной базы относительно выявленных нарушений служат специально формируемые дигитальные платформы, интегрирующие информацию о фактах отступления от области правоохранительных задач и совершения актов «карательного правосудия». Что касается феномена деанонимизации личности, то практическое обеспечение транспарентности сведений о конкретной персоне государственного служащего способствует установлению эмпирического факта, востребованность которого проявляется в достижении злого умысла по отношению к представителям различных органов власти, включая сотрудников органов внутренних дел. В данном случае под злым умыслом следует понимать стремление определенных сил к созданию в обществе обстановки управляемого хаоса, конечной целью которого выступает смена власти или государственный переворот [5, с. 31]. В целях деанонимизации личности сторонников действующего режима, производится накопление и размещение в сети «Интернет» их персональных данных, а также аналогичных данных их близких родственников, включая сведения о принадлежащем им имуществе. Накопленный массив данных передается для последующей обработки в адрес специальной команды, целеполагание которой заключается в составлении санкционных списков должностных лиц, препятствующих продвижению Республики Беларусь по новому пути. Презентуя абрис подлинно демократического стремления к утверждению нового социальнополитического и правозащитного порядка, отмеченные проекты декларируют транспарентность общественного контроля за ходом информационного противостояния с действующими структурами государства и служащими в них лицами. Наряду с отмеченным, оппозиция обещает эвентуальное амнистирование или смягчение уголовного наказания тем государственных служащим, которые продемонстрируют взаимодействие с учреждаемыми параллельными структурами следствия. 
В ноябре 2020 г. лидеры белорусской оппозиции проанонсировали создание Народного трибунала, который займется сбором доказательств «преступлений» действующего режима и предоставит амнистию за захват действующего Президента Республики Беларусь и членов его команды. Кроме того, от имени Народного трибунала опубликован призыв к сотрудникам правоохранительных органов предоставлять видео и другие свидетельства «исполнения преступных приказов», судебный процесс в отношении фигурантов которых должен проходить на платформе движения «Голос». По мнению лидеров оппозиции, каждый белорус сможет проголосовать за обвинение подозреваемых. В случае вынесения народного решения о привлечении данных лиц к ответственности, каждый гражданин в соответствии со ст. 109 УПК Республики Беларусь для осуществления честного суда имеет право захватить и принудительно доставить в орган власти лицо, застигнутое при совершении преступления или попытке скрыться после его совершения. Что касается апеллирования к должностным лицам правоохранительных структур, то в соответствии с программой «Рапорт»плана Народного трибунала, каждому, кто предоставит в адрес трибунала видео-доказательства и другие свидетельства исполнения или участия в исполнении преступных приказов, провозглашена гарантия конфиденциальности и безопасности передаваемого контента [4].

На основании плана Народного трибунала, полный список открытых материалов народной проверки должен публиковаться с нарастающим итогом 20-го числа каждого месяца на сайте «Единой книги регистрации преступлений». Полученный материал передается независимым проектам, лоббирующим расширение санкционных списков, а также в Суд универсальной юрисдикции Литвы. По замыслу лидеров оппозиции, после смены власти в стране, вся накопленная информация в последующем будет использоваться Следственным комитетом и прокуратурой Республики Беларусь [3]. К примеру, основной контент передаваемой в адрес администрации «Telegram»-канала «Черная книга Беларуси» и его областных редакций составляют любые деанонимизированные сведения о правоохранителях, других государственных служащих, судьях и главах госпредприятий, замеченных в преследовании белорусов по политическим мотивам.

Демонстрируя свою приверженность лозунгу «Зима-ваша, веснанаша»польского движения «Солидарность», белорусская оппозиция в наращивания потенциала своих протестных действий на весенний сезон 2021 г. преимущественно использует обширный ареал возможностей сетевых онлайн-технологий и новые дигитальные средства массового воздействия на сознание населения. С учетом изложенного, представляется необходимым заметить следующее: во-первых, цифровая модель информационного противоборства современных общественных отношений содержит новый ряд компонентов наступательности, тотального охвата и творчества акторов социального взаимодействия, апеллирующих к инновационным средствам «Интернет»-коммуникации; во-вторых, в целях достижения кумулятивного эффекта разрушительного воздействия на государственные институции противоборствующей стороны, основные атаки идеологов протестного движения в первое двадцатилетие XXI в. нацелены на правоохранительную сферу, в части подрыва доверия населения к практике деятельности органов правопорядка; в-третьих, онлайн-организация процесса формирования параллельных структур правосудия и следствия выступает центральным фактором современных информационных атак на государство. Отмеченное обстоятельство безусловно заслуживает как правовой оценки, так и конкретных действий по пресечению отмеченного направления протестных действий.

$$
* * *
$$

1. Выступление председателя Совета судей Российской Федерации В.В. Момотова на семинаресовещании председателей советов судей субъектов Российской Федерации 4 февраля 2020 г. / 
Официальный сайт Совета судей Российской Федерации. - URL: http://www.ssrf.ru/news/mieropriiatiia/36595 (дата обращения: 08.01.2021)

2. План Победы. Информационный фронт // Телеграмм-канал «Беларусь головного мозга». - URL: https://t.me/belamova (дата обращения: 18.01.2021)

3. План Народного трибунала // Телеграмм-канал «Светлана Тихановская». - URL: https:/t.me/tsikhanouskaya/421 (дата обращения: 25.01.2021)

4. Телеграмм-канал «BYPOL». - URL: https://t.me/By_Pol (дата обращения: 23.01.2021).

5. Чимаров С.Ю. Феномен деанонимизации личности сотрудника органов внутренних дел: реалии проявления и правовые основы его предотвращения // Вестник Санкт-Петербургской юридической академии. - 2020. - № 4 (49). - С. 31-35.

6. Fukuyama F. Trust. The Social Virtyes and the Creation of Prosperity. - Free Press, 1995. -457 p.

\section{Чимаров С.Ю.}

Актуальные вопросы информационного противоборства в Республике Беларусь: направления онлайн-воздействия на подрыв экономического уклада и общественного порядка в государстве

Санкт-Петербургский университет МВД России (Россия, Санкт-Петербург)

doi: $10.18411 / \mathrm{lj}-02-2021-18$

idsp: ljournal-02-2021-18

\section{Аннотация}

В статье представлен анализ новых технологий информационного противоборства, нацеленных на дестабилизацию обстановки в Республике Беларусь. Выявляя сущностные особенности цифровой активности оппозиции в направлении смены политического режима, автор акцентирует внимание на потенциале новых социальных медиа, действующих в современном «Интернет»-пространстве.

Ключевые слова: общественный порядок, информационное противоборство, цифровая активность, онлайн-воздействие, социальная сеть, сетевое пространство, цифровая платформа.

\section{Abstract}

The article presents an analysis of new technologies of information warfare aimed at destabilizing the situation in the Republic of Belarus. Revealing the essential features of the digital activity of the opposition in the direction of changing the political regime, the author focuses on the potential of new social media operating in the modern «Internet» space.

Keywords: public order, information warfare, digital activity, online impact, social network, network space, digital platform.

Направление движения любого государства по упрочнению демократии и укреплению ареала демократических ценностей неотделимо от вовлечения его в систему координат информационного противоборства. Новый импульс нарастания информационного противостояния генерируется и в случае сомнения общества относительно правильности хода демократических преобразований. Отмеченные обстоятельства выступают: во-первых, в качестве аксиомы политических преобразований на государственном уровне; во-вторых, обретают статус маркера для определения верности проводимого в стране курса демократических новаций или его соответствия/несоответствия велению времени. С учетом отмеченного, важно уточнить понятие «информационное противоборство». Представляется, что под информационным противоборством следует понимать информационный компонент отношений и соответствующие формы противостояния между различными противоборствующими сторонами, целеполагание деятельности которых заключается в достижении победы над вероятным противником в результате информационных атак 